\title{
The bovine tyrosine hydroxylase gene associates in vitro with the nuclear matrix by its first intron sequence ${ }^{\star *}$
}

\author{
Robert Lenartowski ${ }^{1}$, Tomasz Grzybowski ${ }^{2}$, Danuta Miścicka-Śliwka ${ }^{2}$, Waldemar \\ Wojciechowski ${ }^{3}$ and Anna Goc ${ }^{1 凶}$ \\ ${ }^{1} N$. Copernicus University, Institute of General and Molecular Biology, Laboratory of Genetics, \\ Torun; ${ }^{2}$ The Ludwik Rydygier University School of Medical Sciences, Forensic Medicine Institute, \\ Bydgoszcz, Poland; ${ }^{3}$ N. Copernicus University, Institute of General and Molecular Biology, \\ Department of Physiology and Molecular Biology of Plants, Toruń, Poland
}

Received: 14 May, 2003; revised: 06 August, 2003; accepted: 11 August, 2003

Key words: tyrosine hydroxylase, nuclear matrix, scaffold/matrix attachment region (S/MAR), intronic $\mathrm{S} / \mathrm{MAR}$, tissue specificity

\begin{abstract}
Recently we have shown that in vitro binding of the proximal part of the human tyrosine hydroxylase gene to the nuclear matrix is correlated with its transcriptional activity. The strongest binding potential was predicted by computing for the first intron sequence (Lenartowski \& Goc, 2002, Neurosci Lett.; 330: 151-154). In this study a 16 kb fragment of the bovine genomic DNA containing the tyrosine hydroxylase gene was investigated for its affinity to the nuclear matrix. Only a $950 \mathrm{bp}$ fragment encoding the distal part of the first intron, second exon and a few nucleotides of the second intron bound to the nuclear matrix. The binding was independent of the tissue-specific tyrosine hydroxylase gene activation. The fragment was subcloned and sequenced. Computer search pointed to one potential intronic matrix attachment region with two AP1-like sites embedded in the sequence. We conclude that even if the position of the matrix binding region is conserved among the tyrosine hydroxylase genes in mammals, its tissue specificity and/or function is not preserved or is achieved by different mechanisms.
\end{abstract}

\footnotetext{
${ }^{\star}$ Part of these results was presented in a poster form at the W. Mejbaum-Katzenellenbogen Molecular Biology Seminars 7: Chromatin Arrangement and Programmed Cell Death. Wrocław/Szklarska Poręba, Poland, 2000.

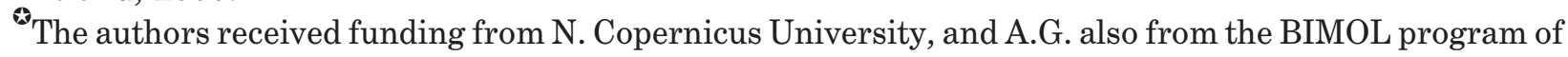
The Foundation for Polish Science.

* Bos taurus tyrosine hydroxylase gene, exons 1 and 2 and partial cds. - GenBank accession number AF510493

${ }^{\bowtie}$ Corresponding author: Anna Goc, N. Copernicus University, Institute of General and Molecular Biology, Laboratory of Genetics, I. Gagarina 9, 87-100 Toruń, Poland; phone: (56) 611 4576, fax: (56) 611 4772, e-mail: goc@cc.uni.torun.pl
}

Abbreviations: S/MAR, scaffold/matrix attachment region; TH, tyrosine hydroxylase; NM, nuclear matrix. 
Structure and function are interdependent also at the level of the cell and its substructures. Differential functioning of a given DNA sequence in specialized tissues is believed to be determined by its nuclear structure. Tissue-specific DNA methylation, nuclease sensitivity, nucleosome phasing and transcription factors are accompanied by an equally specific internal proteinaceous nuclear scaffold called the nuclear matrix (NM). As shown earlier the protein composition of the NM differs among tissues (Fey \& Penman, 1988; Bidwell et al., 1993; Korosec et al., 1997), among differentiation stages of the same tissue (Dworetzky et $a l ., 1990)$ and between normal vs. tumor tissue (Fey \& Penman, 1988; Getzenberg et al., 1991; Partin et al., 1993; Bidwell et al., 1994). As a result some of the chromatin domains determined by scaffold/matrix attachment regions (S/MARs) were demonstrated to be tissue-specific (Ciejek et al., 1983; Robinson et al., 1983; Gasser \& Laemmli, 1986).

Tyrosine hydroxylase (TH) is the first and rate-limiting enzyme of the catecholamine biosynthetic pathway. Kumer and Vrana in their review (1996) have documented that TH and its gene are subjected to multilevel regulation specific for both the developmental stage and the tissue and homeostatic stimuli. Cis-acting regulatory elements involved in transcriptional regulation have been carefully studied especially in the mouse and rat (Kumer \& Vrana, 1996; Schimmel et al., 1999). The regulatory elements which are located in the promoter region are similar in sequence and localization in human (Coker et al.,1988), rat (Coker et al., 1988; Cambi et al., 1989), bovine (D’Mello et al., 1989) and mouse (Iwata et al., 1992) TH genes. However, elements located in the first intron (Meloni et al.,1998; Albanese et al., 2001) and in the $3^{\prime}$ flanking region (Gandelman et al., 1990; Wong et al., 1995) were shown to be specific for the human gene. Our results of an in vitro binding assay and computer search suggested that the first intron of the human $\mathrm{TH}$ gene is also involved in tissue specific binding to the nuclear matrix (Lenartowski \& Goc, 2002).

In the present study we have investigated if the bovine TH gene is associated with the NM. The results suggest that its first intron has S/MAR properties which are not correlated with the transcriptional activity of the gene.

\section{MATERIALS AND METHODS}

Materials. The recombinant phage LambdaDASHII TH carrying $16 \mathrm{~kb}$ of bovine DNA containing the $\mathrm{TH}$ gene was obtained from $\mathrm{Dr}$. B. B. Kaplan and Dr. A. E. Gioio (Medical Center, University Pittsburgh, PA, U.S.A.). Bovine liver and adrenal glands were taken from local slaughter houses and kept at $4^{\circ} \mathrm{C}$. After saline perfusion the tissues were stored at $-75^{\circ} \mathrm{C}$.

Probes. EcoRI fragments (9 and 7 kb, Fig. 1) of the insert cloned in the Lambda DASHII $\mathrm{TH}$ were subcloned into the pUC19 vector. After amplification their DNA was isolated by alkaline lysis and purified through a $\mathrm{CsCl}+\mathrm{EtBr}$ gradient. The plasmid DNA was digested with $E c o$ RI and electrophoresed. The fragments of the bovine DNA were isolated and subsequently restricted with XhoI or BamHI. About $100 \mathrm{ng}$ of the fragments were labelled at their $3^{\prime}$ ends with DIG-11ddUTP using terminal transferase according to the Boehringer Mannheim protocol.

Isolation of nuclei. The method of Berezney \& Coffey (1977) was used.

Nuclear matrix preparation and in vitro binding. The modified method of Mirkovitch et al. (1984) was used for nuclear matrix extraction. Briefly, $10^{7}$ cell nuclei were suspended in $150 \mu \mathrm{l}$ of $3.75 \mathrm{mM}$ Tris $/ \mathrm{HCl}, \mathrm{pH}$ 7.4, $0.05 \mathrm{mM}$ spermine, $0.125 \mathrm{mM}$ spermidine, $20 \mathrm{mM} \mathrm{KCl}, 1 \%$ thiodiglycol, $1 \mathrm{mM}$ sodium tetrathionate, $0.1 \%$ digitonin, $0.1 \mathrm{mM}$ phenylmethylsulfonyl fluoride (PMSF), 0.05 $\mathrm{mM}$ aprotinin and leupeptin each, $1 \mu \mathrm{g} / \mu \mathrm{l}$ pepstatin $\mathrm{A}$ and heated at $37^{\circ} \mathrm{C}$ for $45 \mathrm{~min}$. 
Then $7 \mathrm{ml}$ of $5 \mathrm{mM}$ Hepes/ $\mathrm{NaOH}, \mathrm{pH} 7.4,2$ mM EDTA, pH 8.0, 10 mM lithium 3',5'-diiodosalicylate, $100 \mathrm{mM}$ lithium acetate, $2 \mathrm{mM}$ $\mathrm{KCl}, 0.25 \mathrm{mM}$ spermidine with the same protease inhibitor cocktail as above were added dropwise. After $10 \mathrm{~min}$ incubation at room temperature histone-depleted nuclei were recovered by centrifugation and washed 3 times with digestion buffer $(20 \mathrm{mM}$ Tris/ $\mathrm{HCl} \mathrm{pH}$ 7.4, $20 \mathrm{mM} \mathrm{KCl}, 70 \mathrm{mM} \mathrm{NaCl}, 10 \mathrm{mM} \mathrm{MgCl}_{2}$, $0.05 \mathrm{mM}$ spermine, $0.125 \mathrm{mM}$ spermidine). The pellet of the nuclear matrices was suspended in $150 \mu \mathrm{l}$ of digestion buffer. Two types of in vitro binding reactions were performed. In the A reactions 1-10 $\mu \mathrm{g}$ of sheared Escherichia coli DNA and 75 units of each restriction enzyme were added to the NM preparations; after 15 min the binding was started by adding labeled probes. After $2 \mathrm{~h}$ the same portion of fresh enzymes was added and the reaction continued for a further $2 \mathrm{~h}$. In the $\mathrm{B}$ reactions 75 units of each enzyme were added twice at 0 and $4^{\text {th }} \mathrm{h}$ of $24 \mathrm{~h}$ restriction, then the matrices were pelleted and the supernatant fraction was removed. The $4 \mathrm{~h}$ type $\mathrm{B}$ binding reaction was carried out in fresh $150 \mu \mathrm{l}$ portion of restriction buffer, first 15 min only in the presence of $0.5-10 \mu \mathrm{g}$ of sheared $E$. coli DNA and then with labeled probe. Each type of the restriction and binding reaction was performed at $37^{\circ} \mathrm{C}, 100 \mathrm{ng}$ of the probes were added. The final pellet and supernatant fractions were collected and saved for DNA isolation.

Isolation of DNA bound to the matrix and released to the supernatant. Pellets of nuclear matrices were incubated in $15 \mathrm{mM}$ Tris/HCl, $\mathrm{pH}$ 7.4, $50 \mathrm{mM}$ EDTA, 1\% SDS, $1 \mathrm{mg} / \mathrm{ml}$ proteinase $\mathrm{K}$ and supernatants were adjusted with EDTA, SDS and proteinase $\mathrm{K}$ to the same final concentrations. After over night incubation at $30^{\circ} \mathrm{C}$ phenol:chloroform:isoamyl alcohol extraction was performed and DNA was precipitated with ethanol and dissolved in TE.

Visualization of bound and unbound DNA. The matrix bound DNA and the DNA released to the supernatant were electrophoresed in $1 \%$ agarose gel with $\mathrm{EtBr}$ in $0.5 \times$ TBE. Southern blotting of the DNA to Hybond $\mathrm{N}^{+}$nylon membrane (Amersham) was followed by application of DIG antibodies conjugated with alkaline phosphatase (Boehringer Mannheim) according to the manufacturer's protocol. The membranes were exposed to Rad-Free sheet (Schleicher and Schuell) containing chemiluminescent substrate for alkaline phosphatase and to $\mathrm{X}$ ray film.

DNA sequencing. The NaeI/EcoRI, EcoRI/ $C f r 42 \mathrm{I}$ and Cfr42I fragments of the bovine DNA covering the $+24 /+2094$ region of the TH gene were cloned into pBluescriptII $\mathrm{KS}+$ vector and sequenced from both strands with (-21) M13 forward and M13 reverse primers using the BigDye Primer Cycle Sequencing Kit (Perkin Elmer) according to the manufacturer's protocol. Sequencing products were separated in a $4 \%$ PAGE gel on an ABI Prism $^{\text {TM }} 377$ DNA Sequencer. Data were analysed using the DNA Sequencing Analysis and Sequence Navigator programs (Perkin Elmer).

\section{RESULTS}

Cell nuclei isolated from bovine liver and adrenal medullae were thermally stabilized and their proteins were crosslinked using sodium tetrathionate. Then histones were extracted with a mild detergent (10 mM lithium $3{ }^{\prime}, 5^{\prime}$-diiodosalicylate). The DNA that after such extraction remains associated with the nuclear matrix was digested with restriction enzymes. The nuclear matrices obtained in this way were used for in vitro binding reactions with fragments of bovine DNA containing the TH gene (Fig. 1). Two types of binding reactions (A, B) were performed. They differed in the length of restriction period, simultaneous or separate reactions of restriction and binding and the presence of endogenous competitor DNA during the binding reaction. 
The DNA bound to the nuclear matrix and that released to the supernatant fraction was isolated and analyzed. The amount and origin of the DNA in the supernatant fractions differed between the two types of the binding re-
We assumed that a fragment binds the NM, i.e. it has S/MAR properties, if at least half of its probe remains in the pellet fraction. Most of the in vitro binding experiments were performed with EcoRI/XhoI digested matrices

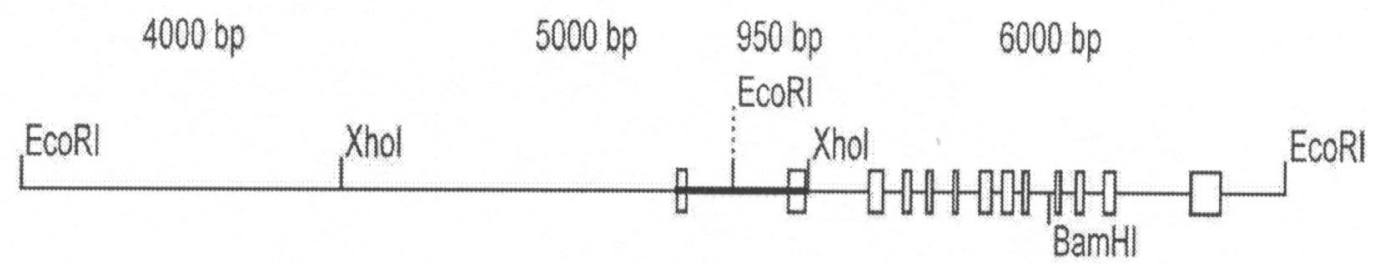

Figure 1. Restriction map of a $16 \mathrm{~kb}$ genomic fragment of bovine TH gene.

Numbers above give EcoRI/XhoI fragment sizes in bp. Rectangles denote exons. The sequenced part of the fragment is marked as a thick bar.

action. The DNA isolated from the pellet fractions consisted of these parts of endogenous DNA and labeled probe which bound to the nuclear matrix. The amount of total DNA from the adrenal medulla $(\mathrm{n}=10)$ and liver $(\mathrm{n}=6)$ remained in the NM preparations was $79.8 \pm 2.9 \%$ and $81.2 \pm 5.7 \%$, respectively (data and probes. Their results are summarized in Table 1.

We have never observed association of the 4000 and 5000 bp probes with the adrenal medulla NM (Fig. 2b, Table 1). The same tendency but less distinct was seen for the liver nuclear matrices (Fig. 3, Table 1). According

Table 1. Summary of the in vitro binding experiments with EcoRI/XhoI digested nuclear matrices and probes.

S, supernatant; P, pellet. Number of experiments in which at least one half of the added probe was found in the pellet or supernatant fraction, respectively, are given.

\begin{tabular}{|c|c|c|c|c|c|c|c|c|c|c|c|c|c|c|c|c|}
\hline \multirow{3}{*}{$\begin{array}{l}\text { Tissue } \\
\text { Probe [bp] } \\
\text { DNA fraction }\end{array}$} & \multicolumn{8}{|c|}{ Adrenal medulla } & \multicolumn{8}{|c|}{ Liver } \\
\hline & \multicolumn{2}{|c|}{4000} & \multicolumn{2}{|c|}{5000} & \multicolumn{2}{|c|}{953} & \multicolumn{2}{|c|}{6000} & \multicolumn{2}{|c|}{4000} & \multicolumn{2}{|c|}{5000} & \multicolumn{2}{|c|}{953} & \multicolumn{2}{|c|}{6000} \\
\hline & $\mathrm{S}$ & $\mathrm{P}$ & $\mathbf{S}$ & $\mathrm{P}$ & $\mathbf{S}$ & $\mathrm{P}$ & $\mathrm{S}$ & $\mathrm{P}$ & $\mathrm{S}$ & $\mathrm{P}$ & $\mathbf{S}$ & $\mathrm{P}$ & $\mathrm{S}$ & $\mathrm{P}$ & $\mathrm{S}$ & $\mathrm{P}$ \\
\hline Reaction type $\mathrm{A}^{1}$ & 9 & 0 & 6 & 0 & 0 & 8 & - & - & 3 & 0 & 3 & 0 & 3 & 0 & 3 & 0 \\
\hline Reaction type $\mathrm{B}^{2}$ & 12 & 0 & 8 & 0 & 4 & 8 & 8 & 0 & 3 & 3 & 4 & 2 & 0 & 8 & 4 & 1 \\
\hline$\Sigma$ & 21 & $\mathbf{0}$ & 14 & $\mathbf{0}$ & 4 & 16 & 8 & 0 & 6 & 3 & 7 & 2 & 3 & 8 & 7 & 1 \\
\hline
\end{tabular}

${ }^{1} 4 \mathrm{~h}$ of simultaneous restriction and binding in the presence of both endogenous [bovine DNA released to the supernatant fraction (17.5 $\pm 4.8 \mu \mathrm{g}$ for the adrenal medulla NM and $20.2 \pm 10.1 \mu \mathrm{g}$ for the liver)] and exogenous (0.5-10 $\mu \mathrm{g}$ of sheared E. coli DNA) competitor DNA; 24 h of restriction $+4 \mathrm{~h}$ of binding in the presence of exogenous competitor DNA.

from control experiments in which restriction reactions lasted $4 \mathrm{~h}$ and no exogenous competitor DNA was added).

The region of bovine genomic DNA used in the in vitro binding experiments covered the entire TH gene and about $8.3 \mathrm{~kb}$ of its proximal and $0.8 \mathrm{~kb}$ of its distal sequences (Fig. 1). to our assumption neither the adrenal medulla (Fig. 2a) nor the liver (Fig. 3) matrices bound the $6000 \mathrm{bp}$ fragment containing most of the TH coding sequence. Only the $950 \mathrm{bp}$ fragment enclosing the distal part of the first intron, second exon and few base pairs of the second intron showed S/MAR properties in 
both studied tissues (Figs. 2b and 3, Table 1). It constitutes a weak S/MAR as its in vitro affinity for NM disappeared when the same sequence was part of a $4300 \mathrm{bp} E c o \mathrm{RI} / \mathrm{BamHI}$ fragment (not shown).

We have subcloned and sequenced fragments of the bovine DNA from $+24 \mathrm{bp}$ in the first exon to $+2094 \mathrm{bp}$ in the second intron of the TH gene (GenBank accession number AF510493). The MAR-Wiz program (http:// www.futuresoft.org/MAR-Wiz/), designed for finding potential S/MARs, was applied to the sequence. Also in this search, like in the in vi-
$950 \mathrm{bp}$ fragment. Inside the $200 \mathrm{bp}$ sequence of the predicted S/MAR two AP1-like elements were also found.

\section{DISCUSSION}

Our preparation method produced matrices very rich in DNA. The DNA retained in the pellet fraction corresponds to a nearly 1000-fold excess over the used amount of the longest probe (6000 bp) and an over 5600-fold excess over the shortest one (950 bp). The

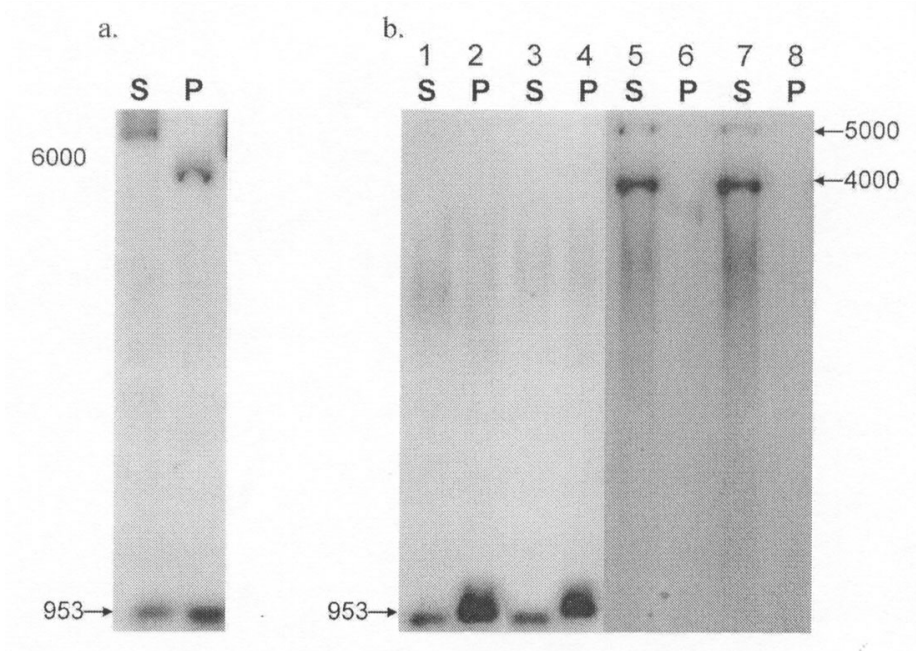

Figure 2. In vitro binding assay type B with bovine NM from adrenal medullae.

$\mathrm{S}$ and $\mathrm{P}, \mathrm{DNA}$ isolated from supernatant and pellet fraction, respectively. a. Reaction with $950+6000 \mathrm{bp}$ probes and $0.5 \mu \mathrm{g}$ of competitor DNA. Whole amount of supernatant DNA and one third of pellet DNA were loaded onto the gel. For unknown reasons the 6000 bp probe had different mobility in $\mathrm{S}$ and $\mathrm{P}$ lanes. b. Reaction with 950 bp (lanes 1-4) and $4000+5000$ bp probes (lanes 5-8) with $5 \mu \mathrm{g}$ (lanes $1,2,5,6)$ or $1 \mu \mathrm{g}$ (lanes 3, 4, 7, 8) of E. coli DNA as an exogenous competitor. Equal parts of DNA from both fractions were analyzed.

tro binding assay, the sequences outside the $950 \mathrm{bp} E c o \mathrm{RI} /$ XhoI fragment (preceding the $+725 \mathrm{bp}$ and following the $+1678 \mathrm{bp}$ ) did not show any NM binding potential. Inside the $950 \mathrm{bp}$ fragment bound in vitro by the matrices MAR-Wiz found on both strands three ORI sequences, three topoisomerase II sites and two stretches longer than 20 nucleotides lacking $\mathrm{G}$ nucleotides on one strand, and predicted one attachment region (Fig. $4 \mathrm{a}$ ).

Additional structural NM binding motifs were defined by Boulikas (1995). Figure 4b shows their presence in the sequence of the high content of DNA in the nuclear matrices resulted partially from using infrequently cutting restriction enzymes (EcoRI, XhoI, BamHI). Additionally, some of the restriction sites can be protected by NM proteins against endonuclease attack as was observed by Käs \& Chasin (1987) and Greenstein (1988). It was also shown (Mirkovitch et al., 1984; Berezney \& Bucholtz, 1981) that after thermal and chemical crosslinking treatments the matrices should be enriched in the protein component. We have confirmed (Lenartowski et al., 1997) by the results of SDS/PAGE experi- 
ments that the matrices obtained in our experiments contained a wide range of proteins (13-205 kDa). Thus conditions were created

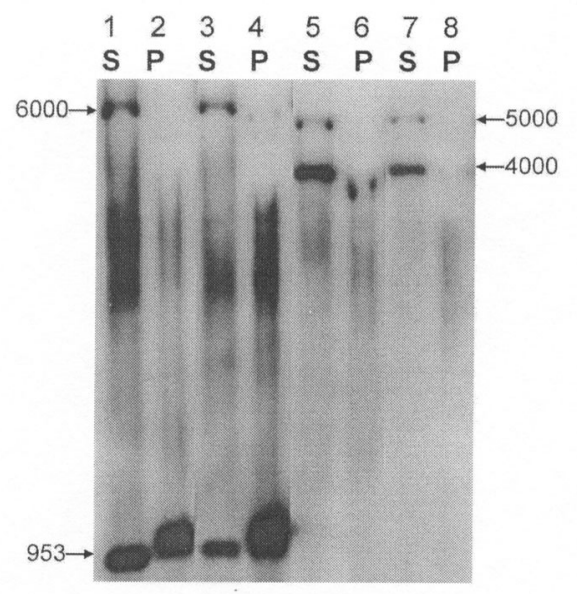

Figure 3. In vitro binding assay type $B$ with the NM from bovine liver and $950+6000$ bp (lanes 1-4), and $4000+5000$ bp probes (lanes 5-8).

Exogenous competitor ( $5 \mu \mathrm{g}$, lanes $1,3,5,7$ or $1 \mu \mathrm{g}$, lanes 2, 4, 6, 8) was added. Equal parts of DNA from both supernatant (S) and pellet (P) fractions were analyzed.

in which on the one hand a huge amount of endogenous DNA is retained in the NM forming complexes with the proteins normally loosely associated with the nuclear scaffold, but on the other hand the diversity of the NM proteins better represented the variety of intranuclear DNA-protein interactions.

The TH gene is active in the adrenal medullae and silent in the liver (Kilbourne et al., 1991). We checked by in vitro binding assay if its DNA is bound to the nuclear matrix of both tissues and if there are any tissue specific differences in its NM affinity. Sixteen thousand base pairs of bovine genomic DNA enclosing the TH gene were assayed. We found that the $950 \mathrm{bp} E c o \mathrm{RI} / \mathrm{XhoI}$ fragment enclosing the distal part of the first intron, second exon and a few base pairs of the second intron binds to the matrices from both tissues. Binding of the same fragment of the TH gene by the nuclear matrices from the liver and adrenal medullae does not necessarily mean that association of the chromatin with the NM is not involved in the tissue specific regulation of the bovine $\mathrm{TH}$ gene. The results of our Southwestern experiments suggested that at least one of the nuclear matrix proteins specific for the adrenal medulla binds the $7 \mathrm{~kb}$ EcoRI region of the bovine $\mathrm{TH}$ gene enclosing the $950 \mathrm{bp}$ fragment (Lenartowski et al., 1997). Thus, different tis-

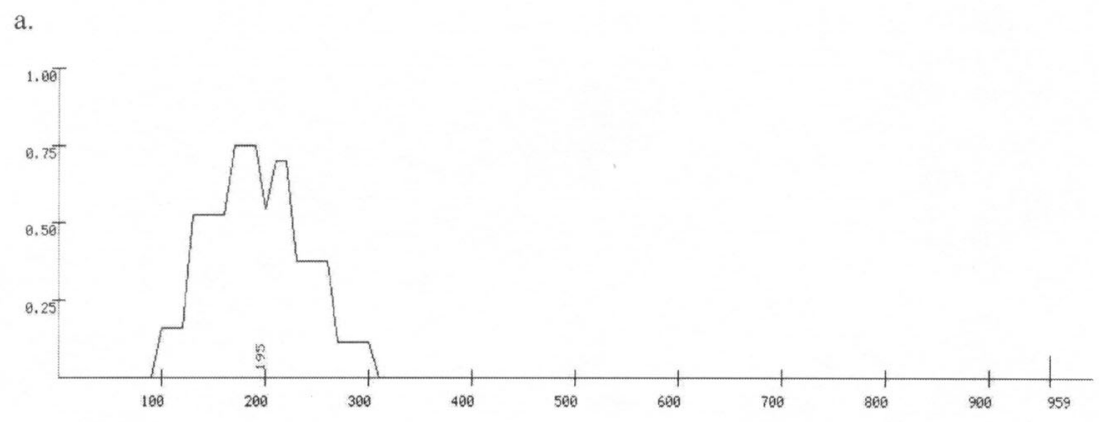

b.

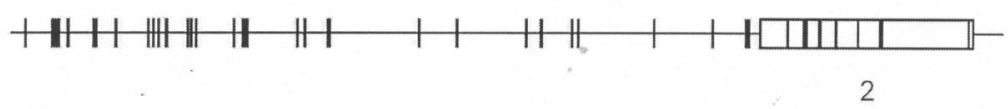

Figure 4. Computer analysis of the $950 \mathrm{bp}$ fragment of the bovine TH gene.

a. MAR-Wiz search. Window width of $100 \mathrm{bp}$ and $10 \mathrm{bp}$ slide distance were used. $\mathrm{x}$ - and y-axis shows the distance from the beginning of the $950 \mathrm{bp}$ fragment and the matrix association potential counted by the program respectively. b. Search for S/MAR structural motifs as defined by Boulikas (1995). Numerous trihomonucleotides, 7-12-nucleotide long streches of purines or pyrimidines, $(\mathrm{RY})_{2-4},(\mathrm{CT})_{3},(\mathrm{CA})_{1-2},(\mathrm{CG})_{1-2},(\mathrm{AG})_{1-3}$ were found and shown as vertical lines. The position of the second exon (D’Mello et al., 1989) is denoted by box and number 2. 
sue specific NM proteins could be involved in the binding of the same DNA region.

The sequencing and subsequent MAR-Wiz search of the $+24 /+2094$ bp fragment of the bovine $\mathrm{TH}$ gene also predicted the existence of a potential matrix attachment region inside the first exon. The length of the putative $\mathrm{S} / \mathrm{MAR}$ is about $200 \mathrm{bp}$ which is in agreement with the experimental data for the matrix binding regions of other genes (Cockerill \& Garrard, 1986; Gasser \& Laemmli, 1986). We checked that the NM proteins from bovine liver and adrenal medullae retarded, in a tissue-specific manner, the gel mobility of this $200 \mathrm{bp}$ intronic fragment of the bovine $\mathrm{TH}$ gene (Lenartowski et al., unpublished). Further experiments will be performed to identify the NM proteins involved in the binding of the $200 \mathrm{bp}$ S/MAR fragment of the bovine TH gene.

A further sequence search showed that the putative $200 \mathrm{bp}$ TH S/MAR contained more structural elements for NM binding and two AP1-like sites. As van Wijnen et al. (1993) have shown that the AP1 factor can be associated with the nuclear matrix, thus raises the possibility that AP1 is involved in the bovine $\mathrm{TH}$ gene interaction with $\mathrm{NM}$ or that an enhancer colocalizes with S/MAR in the first intron of the TH gene. Coexistence of enhancers and S/MARs is well documented (Boulikas, 1995). Several examples of functional enhancers containing AP1 sites which are localized in the first intron have been published (Katai et al., 1992; Gauss et al., 2002; Seshasayee et al., 2000; Cohn et al., 2001; Lu et al., 2001; Joaquin et al., 2002). All of them mediate tissue-specific expression of their genes. If the same is true in the case of the $\mathrm{TH}$ gene, it would give good explanation why proper expression of the gene has never been observed in transgenic animals which always had a reporter gene under control of only the $5^{\prime}$ upstream region of the $\mathrm{TH}$ gene.

The S/MAR localized in the first intron of the TH gene was also found by the MAR-Wiz program in the human sequence. However, in vitro binding of the human $\mathrm{TH}$ sequence to the bovine nuclear matrices was tissue specific to the adrenal medulla matrix only. Both a computer analysis and the in vitro binding assay suggested that more than one S/MAR existed in the $-2300 /+2300$ region of the human $\mathrm{TH}$ gene (Lenartowski \& Goc, 2002). The putative strongest S/MAR was found in the first intron. This intron contained a microsatellite repeat, which is characteristic for primate $\mathrm{TH}$ genes and is involved in the transcriptional regulation of the human gene (Meloni et al., 1998; Albanese et al., 2001). Apart from AP1-like sites no other sequence similarities were found between bovine and human $\mathrm{TH}$ putative intronic S/MARs and neither sequence is A+T-rich. A computer search revealed putative S/MARs and AP1 sites also in the first intron of rat and mouse TH genes (accession numbers M23598 and AF415235). Thus it seems that there is an evolutionary conservation of the position of this particular S/MAR in the $\mathrm{TH}$ genes. The role of the colocalized AP1-like sites and their competition or cooperation with the NM proteins involved in intronic S/MAR binding remain to be elucidated.

We appreciate the kind donation of the Lambda DASHII TH clone by Dr. B. B. Kaplan and Dr. A. E. Gioio (University of Pittsburgh, School of Medicine, Pittsburgh, PA, U.S.A.).

\section{R E F E R E N C E S}

Albanese V, Biguet NF, Kiefer H, Bayard E, Mallet J, Meloni R. (2001) Quantitative effects on gene silencing by allelic variation at a tetranucleotide microsatellite. $\mathrm{Hum} \mathrm{Mol}$ Genet.; 10: 1785-92.

Berezney R, Bucholtz LA. (1981) Dynamic association of replicating DNA fragments with the nuclear matrix of regenerating liver. Exp Cell Res.; 132: 1-13. 
Berezney R, Coffey DS. (1977). Identification of a nuclear protein matrix. Biochem Biophys Res Commun.; 60: 1410-7.

Bidwell JP, van Wijnen AJ, Fey EG, Dworetzky S, Penman S, Stein JL, Lian JB, Stein GS. (1993) Osteocalcin gene promoter-binding factors are tissue-specific nuclear matrix components. Proc Natl Acad Sci U S A.; 90: 3162-6.

Bidwell JP, Fey EG, van Wijnen AJ, Penman S, Stein JL, Lian JB, Stein GS. (1994) Nuclear matrix proteins distinguish normal diploid osteoblasts from osteosarcoma cells. Cancer Res.; 54: 28-32.

Boulikas T. (1995) Chromatin domains and prediction of MAR sequences. Int Rev Cytol.; 162A: 279-388.

Cambi F, Fung B, Chikaraishi D. (1989) 5' flanking DNA sequences direct cell-specific expression of rat tyrosine hydroxylase. $J$ Neurochem.; 53: 1656-9.

Ciejek EM, Tsai MJ, O’Malley BW. (1983) Actively transcribed genes are associated with the nuclear matrix. Nature.; 306: 607-9.

Cockerill PN, Garrard WT. (1986) Chromosomal loop anchorage sites appear to be evolutionarily conserved. FEBS Lett.; 204: $5-7$.

Cohn MA, Hjelmso I, Wu LC, Guldberg P, Lukanidin EM, Tulchinsky EM. (2001) Characterization of Sp1, AP-1, CBF and KRC binding sites and minisatellite DNA as functional elements of the metastasis-associated mts1/S100A4 gene intronic enhancer. Nucleic Acids Res.; 29: 3335-46.

Coker 3rd GT, Vinnedge L, O’Malley KL. (1988) Characterization of rat and human tyrosine hydroxylase genes: functional expression of both promoters in neuronal and non-neuronal cell types. Biochem Biophys Res Commun.; 157: 1341-7.

D’Mello SR, Turzai LM, Gioio AE, Kaplan BB. (1989) Isolation and structural characterization of the bovine tyrosine hydroxylase gene. J Neurosci Res.; 23: 31-40.

Dworetzky SI, Fey EG, Penman S, Lian JB, Stein JL, Stein GS. (1990) Progressive changes in the protein composition of the nuclear matrix during rat osteoblast differentiation. Proc Natl Acad Sci U S A.; 87: 4605-9.

Fey EG, Penman S. (1988) Nuclear matrix proteins reflect cell type of origin in cultured human cells. Proc Natl Acad Sci U S A.; 85: $121-5$.

Gandelman KY, Coker 3rd GT, Moffat M, O’Malley KL. (1990) Species and regional differences in the expression of cell-type specific elements at the human and rat tyrosine hydroxylase gene loci. J Neurochem.; 55: 2149-52.

Gasser SM, Laemmli UK. (1986) The organisation of chromatin loops: characterization of a scaffold attachment site. EMBO J.; 46: 521-30.

Gauss KA, Bunger PL, Quinn MT. (2002) AP-1 is essential for p67(phox) promoter activity. $J$ Leukoc Biol.; 71: 163-72.

Getzenberg RH, Pienta KJ, Huang EY, Coffey DS. (1991) Identification of nuclear matrix proteins in the cancer and normal rat prostate. Cancer Res.; 51: 6514-20.

Greenstein RJ. (1988) Constitutive attachment of murine erythroleukemia cell histone-depleted DNA loops to nuclear scaffolding is found in the beta-major but not the alpha 1-globin gene. DNA.; 7: 601-7.

Iwata N, Kobayashi K, Sasaoka T, Hidaka H, Nagatsu T. (1992) Structure of the mouse tyrosine hydroxylase gene. Biochem Biophys Res Commun.; 182: 348-54.

Joaquin M, Salvado C, Fernandez de Mattos S, Tauler A. (2002) An intronic AP-1 sequence mediates the transcriptional activation of the F-type 6-phosphofructo-2-kinase/fructose-2,6-biphosphatase by serum. Biochim Biophys Acta.; 1574: 131-6.

Katai H, Stephenson JD, Simkevich CP, Thompson JP, Raghow R. (1992) An AP-1-like motif in the first intron of human Pro alfa 1(I) collagen gene is a critical determinant of its transcriptional activity. Mol Cell Biochem.; 118: $119-29$.

Käs E, Chasin LA. (1987) Anchorage of the Chinese hamster dihydrofolate reductase gene to 
the nuclear scaffold occurs in an intragenic region. J Mol Biol.; 198: 677-92.

Kilbourne EJ, Osaka H, Sabban EL. (1991) Hypomethylation of the rat tyrosine hydroxylase gene correlates with its expression in several cell types. Brain Res Dev Brain Res.; 58: $143-6$.

Korosec T, Gerner C, Sauermann G. (1997) Common nuclear matrix proteins in rat tissues. Electrophoresis.; 18: 2109-15.

Kumer SC, Vrana KE. (1996) Intricate regulation of tyrosine hydroxylase activity and gene expression. J Neurochem.; 67: 443-62.

Lenartowski R, Goc A. (2002) Tissue-specific association of the human tyrosine hydroxylase gene with the nuclear matrix. Neurosci Lett.; 330: 151-4.

Lenartowski R, Pluskota W, Wojciechowski W, Goc A. (1997) Cell Mol Biol Lett.; 2: 232.

Lu A, Gupta A, Li C, Ahlborn TE, Ma Y, Shi EY, Liu J. (2001) Molecular mechanisms for aberrant expression of the human breast cancer specific gene 1 in breast cancer cells: control of transcription by DNA methylation and intronic sequences. Oncogene.; 20: 5173-85.

Meloni R, Albanese V, Ravassard P, Treilhou F, Mallet J. (1998) A tetranucleotide polymorphic microsatellite, located in the first intron of the tyrosine hydroxylase gene, acts as a transcription regulatory element in vitro. Hum Mol Genet.; 7: 423-8.

Mirkovitch J, Mirault ME, Laemmli UK. (1984) Organization of the higher-order chromatin loop: specific DNA attachment sites on nuclear scaffold. Cell.; 39: 223-32.
Partin AW, Getzenberg RH, CarMichael MJ, Vindivich D, Yoo J, Epstein JI, Coffey DS. (1993) Nuclear matrix protein patterns in human benign prostatic hyperplasia and prostate cancer. Cancer Res.; 53: 744-6.

Robinson SI, Small D, Idzerda R, McKnight GS, Vogelstein B. (1983) The association of transcriptionally active genes with the nuclear matrix of the chicken oviduct. Nucleic Acids Res.; 11: 5113-30.

Schimmel JJ, Crews L, Roffler-Tarlov S, Chikaraishi DM. (1999) $4.5 \mathrm{~kb}$ of the rat tyrosine hydroxylase 5 ' flanking sequence directs tissue specific expression during development and contains consensus sites for multiple transcription factors. Brain Res $\mathrm{Mol}$ Brain Res.; 74: 1-14.

Seshasayee D, Geiger JN, Gaines P, Wojchowski DM. (2000) Intron 1 elements promote erythroid-specific GATA-1 gene expression. $J$ Biol Chem.; 275: 22969-77.

van Wijnen AJ, Bidwell JP, Fey EG, Penman S, Lian JB, Stein JL, Stein GS. (1993) Nuclear matrix association of multiple sequence-specific DNA binding activities related to SP-1, ATF, CCAAT, C/EBP, OCT-1, and AP-1. Biochemistry.; 32: 8397-402.

Wong SC, Moffat MA, Coker GT, Merlie JP, O'Malley KL. (1995) The 3' flanking region of the human tyrosine hydroxylase gene directs reporter gene expression in peripheral neuroendocrine tissues. J Neurochem.; 65: $23-31$. 